\title{
Effect of long-term physical training and detraining on myocyte structure and connective tissue of Wistar rat's ventricle: preliminary experiment in rats
}

\author{
Dewi I. S. Santoso, ${ }^{1}$ Susy O. Lontoh, ${ }^{2}$ Puspita E. Wuyung, ${ }^{3}$ Sutjahjo Endardjo ${ }^{3}$ \\ ${ }^{1}$ Department of Physiology, Faculty of Medicine, Universitas Indonesia, Jakarta, Indonesia \\ ${ }^{2}$ Department of Physiology, Faculty of Medicine, Universitas Tarumanagara, Jakarta, Indonesia. Master Programme in \\ Biomedical Sciences, Faculty of Medicine, Universitas Indonesia \\ ${ }^{3}$ Department of Pathology Anatomy, Faculty of Medicine, Universitas Indonesia, Jakarta, Indonesia
}

\begin{abstract}
Abstrak
Latar belakang: Penelitian ini bertujuan untuk mempelajari perubahan tatanan miokardium ventrikel pada model hipertrofi fisiologik akibat latihan fisik jangka panjang dan detraining.

Metode: Tikus galur Wistar jantan (8 minggu), berat 150-250g dibagi menjadi 3 kelompok. Kelompok perlakuan terdiri dari 2 sub grup, yi. diberi latihan fisik selama 4 dan 12 minggu. Semua kelompok perlakuan dibagi menjadi 2 kelompok lagi, satu kelompok dilakukan detraining selama 4 minggu sedang satu kelompok lagi tidak. Pada akhir minggu ke 4 dan 12 untuk kelompok kontrol dan perlakuan, dan minggu ke 8 dan 16 untuk kelompok training-detraining dilakukan pembedahan untuk mempelajari perubahan morfometrik dan struktur histopatologi miokardium.

Hasil: Terdapat perbedaan bermakna berat jantung dan tebal ventrikel kiri pada kelompok aerobik dan anaerobik 4 minggu dibandingkan kontrol (751,0 $\pm 36,5 \mathrm{gr}$ dan 791,1 $\pm 15,8 \mathrm{gr}$ vs $588 \pm 19,4 \mathrm{gr}),(3,34 \pm 0,12 \mathrm{~mm}$ dan 3,19 $\pm 0,1$ $\mathrm{mm}$ vs 2,80 $\pm 0,07 \mathrm{~mm})$. Berat jantung kelompok erobik dan anerobik 12 minggu mengalami peningkatan dibandingkan kelompok kontrol (1030,8 $\pm 82,4 \mathrm{gr}$ dan 1140,4 \pm 0,24 gr vs 871,6 $\pm 62,0 \mathrm{gr}$ ). Volumejantung kelompok erobik dan anerobik 12 minggu mengalami peningkatan perbedaan bermakna $(3,58 \pm 0,31 \mathrm{~mm}$ dan 4,04 $\pm 0,30 \mathrm{~mm})$ dibandingkan kelompok kontrol $(2,82 \pm 0,14 \mathrm{~mm})$. Panjang serat otot jantung dalam ukuran log 10 untuknormalisasi data. Terdapat penambahan panjang bermakna pada sel otot jantung kelompok 4 minggu erobik dan anerobik $(1,09 \pm 0,08 \mu \mathrm{m}$ dan 1,00 $\pm 0,12 \mu \mathrm{m})$ dibandingkan dengan kelompok kontrol $(0,73 \pm 0,1 \mu \mathrm{m})$. Lebar sel otot jantung kelompok 4 minggu erobik dan anerobik menunjukkan peningkatan bermakna dibandingkan dengan kelompok kontrol (5,38 $\pm 1,3 \mu \mathrm{m}$ dan 5,5 $\pm 2,11 \mu \mathrm{m})$ vs $(2,74 \pm 0,53 \mu \mathrm{m})$. Penurunan bermakna dijumpai pada panjang sel otot jantung kelompok erobik 4 minggu yang menjalani detraining (0,94 $\pm 0,08 \mu \mathrm{m})$ dibandingkan kelompok latihan $(1,09 \pm 0,08 \mu \mathrm{m})$. Didapatkan peningkatan bermakna panjang sel otot jantung kelompok 12 minggu erobik dan anerobik $(1,3 \pm 0,04 \mu \mathrm{m}$ dan 1,2 $\pm 0,07 \mu \mathrm{m})$ dibandingkan dengan kelompok kontrol (0,95 $\pm 0,69 \mu \mathrm{m})$ dan pertambahan lebar sel otot jantung kelompok 12 minggu erobik dan anerobik $(7,3 \pm 1,01 \mu \mathrm{m}$ dan 6,44 \pm $0,08 \mu \mathrm{m})$ dibandingkan kontrol $(4,52 \pm 0,91 \mu \mathrm{m})$.
\end{abstract}

Kesimpulan: Latihan erobik dan anerobik jangka panjang pada tikus dewasa muda menimbulkan hipertrofi dinding dan pelebaran rongga ventrikel kiri, dan juga fibrosis ringan. Pada periode detraining terjadi regresi tebal dan rongga ventrikel, dan penyusutan luas daerah fibrosis ventrikel ke keadaan normal. (Med J Indones 2011; 20:271-7)

\begin{abstract}
Background: This study was aimed to evaluate the structural changes of the ventricular myocardium in a physiological hypertrophic heart model due to long term aerobic and anaerobic physical training and detraining.

Methods: In-vivo experimental study on Wistar rats (8 weeks old), weighing 150-250 grams who were divided into 3 large groups: control group, aerobic exercise group and anaerobic exercise group. Aerobic and anaerobic training were conducted for 4 and 12 weeks. At the end of 4 and 12 weeks of exercising, half of each exercising group was sacrificed to study the morphological and histopathological changes in myocardial structure. The remaining of the groups were given a period of 4 weeks of detraining and sacrificed at the end of the 8th and 16th week.

Results: Significant differences in heart weight and left ventricular wall thickness was found in the 4 weeks of aerobic and anaerobic group compared to the control group $(751.0 \pm 36.5 \mathrm{gr}$ and $791.1 \pm 15.8 \mathrm{gr}$ vs $588 \pm 19.4 \mathrm{gr}),(3.34 \pm 0.12 \mathrm{~mm}$ and $3.19 \pm 0.1 \mathrm{~mm}$ vs $2.80 \pm 0.07 \mathrm{~mm})$. An increase in heart mass weight was observed in both 12 weeks aerobic and anaerobic training group compared to the control group $(1030.8 \pm 82.4 \mathrm{gr}$ and $1140.4+0.24 \mathrm{gr}$ vs $871.6 \pm 62.0 \mathrm{gr})$. Heart volume of the 12 weeks aerobic-anaerobic groups showed a significant increase $(3.58 \pm 0.31 \mathrm{~mm}$ and $4.04 \pm 0.30 \mathrm{~mm})$ compared to the control group $(2.82 \pm 0.14 \mathrm{~mm})$. The length of cardiomyocyte was in $\log 10$ to normalize the data. There was a significant increase in the length of the cardiac muscle cells of the 4 weeks aerobic and anaerobic group $(1.09 \pm 0.08 \mu \mathrm{m}$ and $1.00 \pm 0.12$ $\mu \mathrm{m})$ compared with the control group $(0.73 \pm 0.1 \mu \mathrm{m})$. Width of heart muscle cells in the 4 weeks aerobic-anaerobic group showed a significant increase when compared to the control group $(5.38 \pm 1.3 \mu \mathrm{m}$ and $5.5 \pm 2.11 \mu \mathrm{m})$ vs $(2.74 \pm 0.53 \mu \mathrm{m})$. Significant reduction in the length of cardiac muscle cells in the detrained 4 weeks aerobic group $(0.94 \pm 0.08 \mu \mathrm{m})$ was found when compared to the treatment group $(1.09 \pm 0.08 \mu \mathrm{m})$. Significant differences were found between the length of cardiac muscle cells in the 12 weeks aerobic-anaerobic groups $(1.3 \pm 0.04 \mu \mathrm{m}$ and $1.2 \pm 0.07 \mu \mathrm{m})$ compared to the control group $(0.95 \pm$ $0.69 \mu \mathrm{m})$. Significant width increments of heart muscle cells was found in the 12 weeks aerobic-anaerobic groups $(7.3 \pm 1.01$ $\mu \mathrm{m}$ and $6.44 \pm 0.08 \mu \mathrm{m})$ compared to the control group $(4.52 \pm 0.91 \mu \mathrm{m})$.
\end{abstract}

Conclusion: Long term aerobic and anaerobic training causes an increase in both wall thickness and diameter of the left ventricular cavity, as well as slight fibrosis. The increase in wall thickness, diameter, and fibrosis diminish during detraining period. (Med J Indones 2011; 20:271-7)

Keywords: Aerobic/anaerobic exercise, detraining, fibrosis, myocardial structure 
Regular physical training induces cardiovascular adaptation such as left ventricular hypertrophy (LVH). Left ventricular hypertrophy is a characteristic adaptive response of the heart towards pressure or volume overload. Exercise induced cardiac hypertrophy is associated with an increase in systolic and diastolic function. ${ }^{1,2,3}$ However, routine electrocardiogram (ECG) examination in athletes at our department often revealed an enlarged heart accompanied by abnormalities in the electrical conduction of the heart (arrhythmia), with or without clinical symptoms.

Framingham studies on population have provided evidence that the presence of LVH increases risk factor for cardiovascular disease. The pattern of LVH on electrocardiogram (ECG-LVH) is associated with an increased incidence of heart failure, myocardial infarction, coronary heart disease and stroke. ${ }^{4}$

Classical concept states that LVH would start as an adaptive, beneficial response in order to normalize wall stress. With progression of the disease, deterioration to maladaptive hypertrophy and further on to heart failure could occur. Recent findings in genetic models of myocardial hypertrophy have provided the molecular basis for a novel concept, which favors the existence of either compensatory or maladaptive forms of hypertrophy (cardiac mass), of which only the latter leads the way to cardiac failure ${ }^{5,6}$ However, most studies using animal model was conducted under pathological conditions such as an increase in blood pressure.

The purpose of this experiment is to study the structural changes of the ventricularmyocardium in a physiological hypertrophic heart model due to long term aerobic and anaerobic physical training and detraining; whether it causes pathological changes in the myocardial structure of the left ventricle and whether a period of detraining causes recovery or regression of the changes in left ventricular myocardial structure.

\section{METHODS}

This study was conducted at the Biochemistry laboratory Faculty of Medicine Universitas Indonesia, from October 2010 through April 2011. Ethical clearance was obtained from Ethical Committe of FMUI.

\section{Subjects}

Sixty young adult Wistar rats (8 weeks old), weighing 150-250 gram were divided into 3 large group: control group, aerobic exercise group and anaerobic exercise group. Standard diet ad libitum and vitamin supplement was given. Room temperature was maintained at $23^{\circ} \pm$ $1^{\circ} \mathrm{C}$ with 12 hours of day light and 12 hours of darkness. The control group was divided into 2 sub-groups: 4 weeks group and 12 weeks group. Each exercising group were divided into 4 subgroups: 4 weeks exercise, 4 weeks exercise - 4 weeks detraining, 12 weeks exercise and 12 weeks exercise - 4 weeks detraining respectively. After 1 week of adaptation, aerobic exercise was conducted on animal treadmill (T-6000) with a speed of $20 \mathrm{~m} /$ minute for 20 minutes, with a 90 seconds period of rest every 5 minutes running. The anaerobic group was exercised on a treadmill with a speed of $35 \mathrm{~m} /$ minutes for 15 minutes, with a 90 seconds period of rest after 5 minutes running. The exercises were conducted for 5 consecutive days/week followed by 2 days of rest at the end of each week.

The rats were decapitated and thoracotomy was performed by incision of the skin and muscle tissue at the midline of the chest and cutting of the rib cartilage (in costosternal joint). The heart was then taken after separating it from the blood vessels and the lining of the heart.

Measurement of body weight, heart mass, left ventricle wall thickness and left ventricular chamber volume were taken. The heart was weighed with a precision analytical scale with a range of 0.1 to $160 \mathrm{~g}$. The heart was cut horizontally, the left ventricle was taken and measurements of the ventricular cavity largest diameter and left ventricular wall thickness were conducted using calipers with a sensitivity of 0.01 . The tissue was fixed using $10 \%$ buffered formalin, embedded in paraffin, cut (thickness of 4-5 $\mu \mathrm{m}$ ), and stained.

HE and Masson's trichrome staining were used for histological studies using the advanced staining protocol. ${ }^{7}$ Cardiomyocyte length and width (in HE staining) and the spread of fibrotic tissues (inMasson's trichrome staining) were analyzed using Image $\mathrm{J}$ program.

\section{Data Collection}

Cardiac hypertrophy is determined by comparing the heart weight, heart chamber volume and left ventricular wall mass against the control group. Histo-morphometric studies of the left ventricle cardiomyocytes was conducted using a light microscope (Electric Binocular Olympus). Analysis of cardiomyocyte including the length and diameter (in micrometer) and fibrotic area dispersion was conducted using the Image $J$ program (Java-based image processing developed at the National Institues of Health) on longitudinal section of the left ventricle. All images were stored into a computer as jpg format. Cells that were shown in pixels were standardized using a counting chamber and 
computed into micrometer using the Image J program. Fibrotic tissues using Masson's trichrome staining were computed based on the tissue's color (bluish) compared to surrounding area (in percentage).

\section{Analysis}

All data were analyzed using independent t-test to determine the mean difference between each treatment groups to the control group, with a significance level of $\mathrm{p}<0.05$.

\section{RESULTS}

\section{Morphometric assessment}

Changes in body weight, heart mass weight, left ventricular chamber volume and left ventricular wall mass thickness after 4 and 12 weeks of exercise are shown in Table 1 and Table 2.

A significant increase in body weight was found in the 4 week aerobic and anaerobic group compared to the control group (Table 1). Increasing body weight after a period of 4 weeks detraining was also observed, although the increase was not statistically significant. Similarly, measurements of heart weight, left ventricular wall thickness and ratio of left ventricular wall thickness/left ventricular volume in the 4 week aerobic and anaerobic group showed increased values when compared to the control group. The results were statistically significant $(p<0.05)$ for heart weight and left ventricular thickness in the 4 weeks aerobic/ anaerobic group compared to the control group. In the group who underwent a 4 week of detraining period after 4 weeks aerobic and anaerobic exercise, a decline in left ventricle wall thickness was seen when compared to the 4 weeks aerobic and anaerobic exercising group. There was also a reduction in cardiac volume of the treatment group when compared to the control group.
The left ventricular wall thickness/left ventricular volume ratio of the detrained 4 weeks aerobic group is slightly lower than the 4-week aerobic group although the difference was not statistically significant. The ratio of left ventricular wall thickness/left ventricular volume of the detrained 4 weeks anaerobic group is slightly higher than the 4 weeks anaerobic group.

The results of measurements of body weight of the 12 weeks anaerobic group showed a significant increase $(p<0.05)$ compared to the control group $(344.17 \pm 11.06$ $\mathrm{g}$ vs $258.33 \pm 13.76 \mathrm{~g}$ ), while the 12 weeks aerobic group showed a body weight nearly equal to the control group (Table 2). A gain in body weight is also observed in the detrained 12 weeks aerobic and anaerobic group. An increase in heart mass weight was observed in the 12 weeks aerobic and anaerobic group, although significant difference $(p<0.05)$ was only found in the 12 week anaerobic group compared to the control group $(1140.4 \pm 0.24 \mathrm{~g}$ vs $871.6 \pm 62.0 \mathrm{~g})$. In the detrained 12 weeks aerobic and anaerobic group, a decrease in heart weight was seen. A significant increase in the heart volume was found in the 12 weeks aerobic and anaerobic group $(3.58 \pm 0.31 \mathrm{~mm}$ and $4.04 \pm 0.30 \mathrm{~mm})$ compared to the control group $(2.82 \pm 0.14 \mathrm{~mm})$. In the detrained 12 weeks of aerobic and anaerobic group heart volume was decreased compared to the 12 weeks aerobic and anaerobic exercising group. In both 12 weeks aerobic and anaerobic exercising group, the left ventricle wall thickness was increased although a significant increase was only observed in the 12 weeks anaerobic group $(\mathrm{p}<0.05)$. In the detrained 12 weeks aerobic and anaerobic group, a reduction in heart volume was observed. A decrease in the ratio of wall thickness/left ventricular volume was also observed in the treated group when compared to the control group. The wall thickness/left ventricular volume ratio was slightly decreased in the detrained 12 weeks of aerobic group, while in the detrained 12 weeks anaerobic group this ratio was slightly increased.

Table 1. Morphometric measurement of the heart after 4 weeks of aerobic/anaerobic exercise

\begin{tabular}{|c|c|c|c|c|c|}
\hline \multirow{3}{*}{ PARAMETER } & \multirow{3}{*}{$\begin{array}{c}\text { CONTROL } \\
\text { GROUP } \\
4 \text { WEEKS }\end{array}$} & \multicolumn{4}{|c|}{ TREATMENT GROUP } \\
\hline & & \multicolumn{2}{|c|}{ Aerobic } & \multicolumn{2}{|c|}{ Anaerobic } \\
\hline & & 4 wks & 4 wk detraining & 4 wks & 4 wk detraining \\
\hline Body weight (gram) & $186.87 \pm 5.58$ & $220.83 \pm 10.28^{*}$ & $222.50 \pm 9.01$ & $229.00 \pm 10.63^{*}$ & $236.67 \pm 16.21$ \\
\hline Heart mass weight (mg) & $588.1 \pm 19.4$ & $751.0 \pm 36.5^{*}$ & $859.0 \pm 50.3$ & $791.1 \pm 15.8 *$ & $796.7 \pm 31.1$ \\
\hline Heart chamber (mm) & $3.00 \pm 0.16$ & $2.85 \pm 0.30$ & $2.47 \pm 0.39$ & $2.95 \pm 0.41$ & $2.19 \pm 0.23$ \\
\hline LV wall mass (mm) & $2.80 \pm 0.07$ & $3.34 \pm 0.12 *$ & $2.83 \pm 0.21$ & $3.19 \pm 0.1 *$ & $2.94 \pm 0.07$ \\
\hline Wall thickness /LV Volume & 0.93 & 1.17 & 1.15 & 1.08 & 1.34 \\
\hline
\end{tabular}


Tabel 2. Morphometric measurement of the heart after 12 weeks of aerobic/anaerobic exercise

\begin{tabular}{|c|c|c|c|c|c|}
\hline \multirow{3}{*}{ PARAMETER } & \multirow{3}{*}{$\begin{array}{l}\text { CONTROL } \\
\text { GROUP } \\
12 \text { WEEKS }\end{array}$} & \multicolumn{4}{|c|}{ TREATMENT GROUP } \\
\hline & & \multicolumn{2}{|c|}{ Aerobic } & \multicolumn{2}{|c|}{ Anaerobic } \\
\hline & & $12 \mathrm{wks}$ & 4 wk detraining & $12 \mathrm{wks}$ & $4 \mathrm{wk}$ detraining \\
\hline Body weight (gram) & $258.33+13.76$ & $257.83 \pm 23.82$ & $303.33 \pm 11.30$ & $344.17 \pm 11.06^{*}$ & $381.67 \pm 14.30$ \\
\hline Heart mass weight (mg) & $871.6 \pm 62.0$ & $1030.8 \pm 82.4$ & $919.6 \pm 56.5$ & $1140.4 \pm 0.24 *$ & $1130 \pm 0.05$ \\
\hline Heart chamber (mm) & $2.82 \pm 0.14$ & $3.58 \pm 0.31 *$ & $3.50 \pm 0.31$ & $4.04 \pm 0.30 *$ & $3.25 \pm 0.47$ \\
\hline LV wall mass (mm) & $3.17 \pm 0.14$ & $3.40 \pm 0.10$ & $3.26 \pm 0.19$ & $3.61 \pm 0.14 *$ & $3.02 \pm 0.28$ \\
\hline Wall thickness / LV Volume & 1.12 & 0.95 & 0.93 & 0.89 & 0.93 \\
\hline
\end{tabular}

Mean $\pm \mathrm{SE}, *$ statistically significant difference compared to the control group $(\mathrm{p}<0.05$, independent $\mathrm{t}$-test $)$

\section{Histomorphometric assessment}

\section{Cardiomyocyte length and width}

Changes of myocyte length and width after training and detraining can be seen in Table 3. The length of cardiomyocytes was in $\log 10$ to normalize the data.

Table 3. Cardiomyocyte length and width in the various groups

\begin{tabular}{lcc}
\hline & $\begin{array}{c}\text { Length }(\boldsymbol{\mu m}) \\
\log \mathbf{1 0}\end{array}$ & Width $(\boldsymbol{\mu m})$ \\
\hline Control after 4 weeks & $0.73 \pm 0.1$ & $2.74 \pm 0.53$ \\
Aerobic 4 weeks & $1.09 \pm 0.08^{*}$ & $5.38 \pm 1.3^{*}$ \\
Aerobic 4 weeks, detraining & $0.94 \pm 0.08^{\Delta}$ & $5.03 \pm 1.3$ \\
Anaerobic 4 weeks & $1.00 \pm 0.12^{*}$ & $5.5 \pm 2.11^{*}$ \\
Anaerobic 4 weeks, detraining & $0.9 \pm 0.45$ & $5.5 \pm 0.59$ \\
Control after 12 weeks & $0.95 \pm 0.69$ & $4.52 \pm 0.91$ \\
Aerobic 12 weeks & $1.3 \pm 0.04^{*}$ & $7.3 \pm 1.01^{*}$ \\
Aerobic 12 weeks, detraining & $1.01 \pm 0.11^{\Delta}$ & $6.22 \pm 1.54$ \\
Anaerobic 12 weeks & $1.2 \pm 0.07^{*}$ & $6.44 \pm 0.88^{*}$ \\
Anaerobic 12 weeks, detraining & $0.89 \pm 0.15^{\Delta}$ & $5.45 \pm 2.16$ \\
\hline
\end{tabular}

Mean \pm SE, *statistically significant difference compared to the control group (p $<0.05$, independent t-test), ${ }^{\Delta}$ statistically significant difference compared to the aerobic/anaerobic group $(\mathrm{p}<0.05$, independent t-test)

From the histological examination of ventricular myocytes, a significant increase $(p<0.05)$ in the heart muscle cell length was found in the 4 weeks aerobicanaerobic treatment groups compared to the control group. Similarly, the width measurements of heart muscle cells in 4 weeks treatment groups showed a significant increase $(p<0.05)$ compared to the control group. A period of 4 weeks detraining after aerobic and anaerobic exercise showed a decrease in the length and width of heart muscle cells compared to the exercise group. A significant decrease $(p<0.05)$ was found in the length of cardiac muscle cells of the aerobic exercising group that underwent detraining.

Table 3 also shows the changes in length (in $\log 10$ to normalize the data) and width of cardiac muscle cells of the 12 weeks aerobic and anaerobic group compared with the control group. The results showed a statistically significant increase of the myocyte length in the 12 weeks aerobic and anaerobic group compared to the control group. The width of cardiac muscle cells in the 12 weeks aerobic and anaerobic group compared to the control group showed a significant increase compared to the control group. A decrease in the length and width of myocyte was observed in both detrained 12 weeks aerobic and anaerobic group. Statistically significant reduction occurred in the length of the detrained 12 weeks aerobic and anaerobic group.

\section{Fibrotic area measurement}

To determine the degree of myocardial damage caused by physical exercise, extensive measurements of the fibrotic area was carried out. Visible increase in fibrosis in the 4 weeks aerobic and anaerobic group compared to the control group was found, although the differences were not statistically significant (Table 4). Detraining period for 4 weeks in the 4 weeks aerobic and anaerobic group showed reduced fibrosis area close to the control group (Figure 1).

Fibrotic area percentage after 12 weeks of aerobic and anaerobic physical exercise can be seen in Table 5 .

Tabel 4. Fibrotic area percentage after 4 weeks and after 12 weeks of aerobic and anaerobic exercise and detraining

\begin{tabular}{|c|c|c|c|c|c|}
\hline \multirow{2}{*}{\multicolumn{2}{|c|}{ PARAMETER }} & \multicolumn{4}{|c|}{ TREATMENT GROUP } \\
\hline & & \multicolumn{2}{|c|}{ Aerobic } & \multicolumn{2}{|c|}{ Anaerobic } \\
\hline & & 4 wks & 4 wk detraining & 4 wks & 4 wk detraining \\
\hline $\begin{array}{l}\text { Fibrotic area controlm group } \\
4 \text { weeks }\end{array}$ & $17.54 \pm 1.41$ & $22.36 \pm 1.27$ & $18.51 \pm 0.64$ & $23.59 \pm 3.69$ & $17.78 \pm 3.13$ \\
\hline $\begin{array}{l}\text { Fibrotic area controlm group } \\
12 \text { weeks }\end{array}$ & $19.26 \pm 1.64$ & $28.52 \pm 0.02$ & $22.5 \pm 0.81$ & $24.71 \pm 1.4$ & $19.63 \pm 0.55$ \\
\hline
\end{tabular}



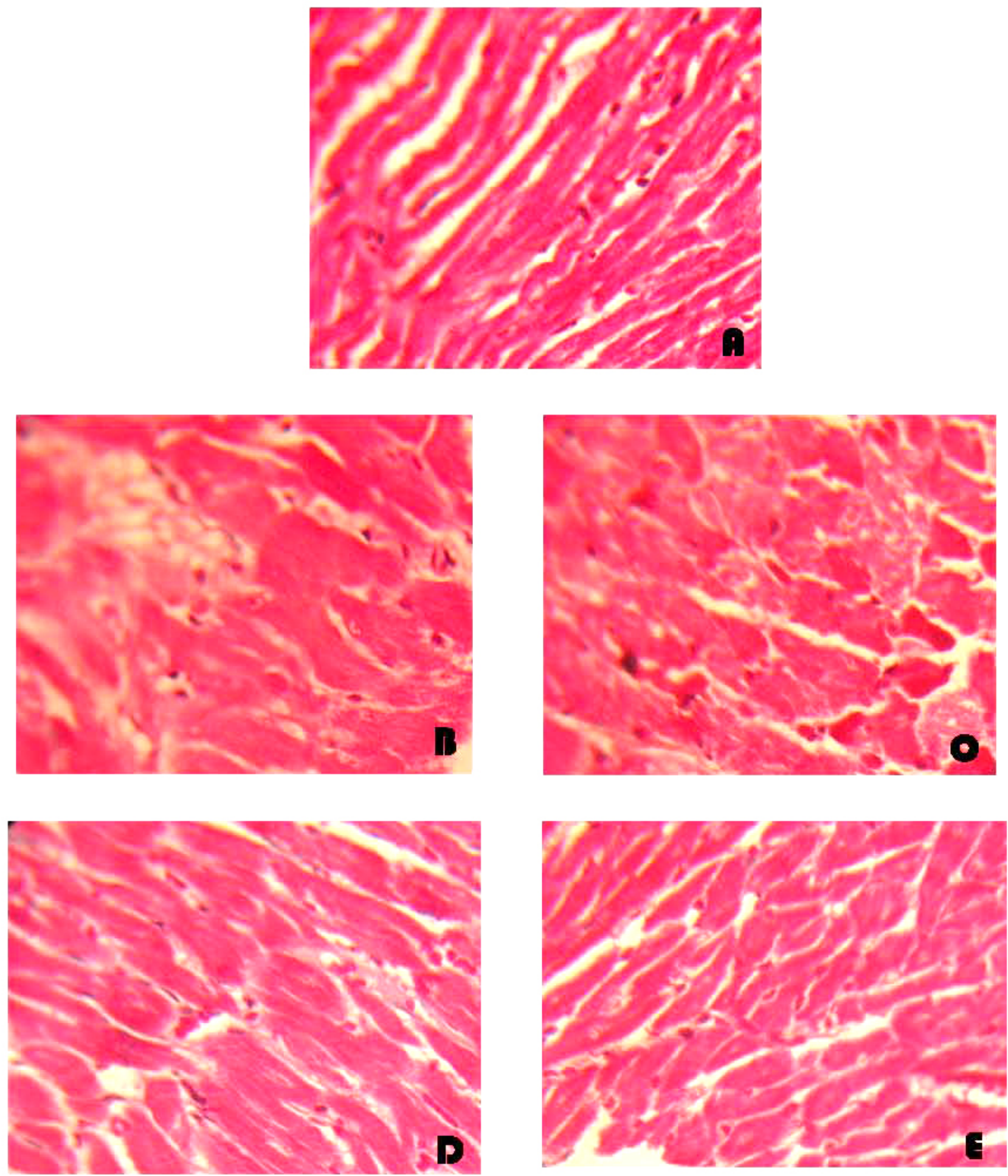

Figure 1. Microphotograph of cardiac muscle tissue to show the fibrotic area. Photographed using olympus CH20 microscope camera magnification $10 \times 40$.

$A=$ Control group, $B=4$ weeks aerobic group $C=4$ weeks detrained-4 weeks aerobic group, $D=4$ weeks anaerobic group, $E=$ 4 weeks detrained-4 weeks anaerobic group. 


\section{DISCUSSION}

Increase in body weight and heart mass weight in both control group (4 weeks and 12 weeks) was observed and might be associated to normal growth and development of young adult rats. An increase in body weight and heart mass was also observed in the 4 weeks aerobic/ anaerobic exercising group, 4 weeks aerobic/anaerobic exercising group followed by detraining and 12 weeks aerobic/anaerobic training group. A decrease in heart mass weight was seen only in the 12 weeks aerobic/ anaerobic training group, which underwent a 4 week detraining period. It appears that the gain in heart mass weight is not entirely caused by physical training but partly due to growth and gain in body weight. The effect of detraining on heart mass weight was found only in the 12 weeks aerobic/anaerobic training group. A 12 weeks training period may be considered as a long term training period, since the average age of Wistar rats is about 2-2.5 years old.

An increase in heart volume and left ventricular wall mass was observed more clearly in the anaerobic exercising group (12 weeks exercising). However, the walls mass/ventricular volume ratio is higher in the aerobic group. Both aerobic and anaerobic exercise increases the ventricular wall mass/volume ratio after 4 weeks of training, followed by a decrease in the ratio after 12 weeks of exercise when compared to the control group, due to ventricular cavity enlargement. It is concluded that the thickening of ventricular wall mass occurs in the early stages of exercising, followed by enlargement of the ventricular cavity.

Histological studies revealed a significant increase in the length and width of myocyte following 4 and 12 weeks of aerobic or anaerobic exercising. A period of 4 weeks of detraining resulted in a regression of the myocyte length and width. Further, using the Image $\mathrm{J}$ program it was observed that aerobic and anaerobic exercise induced fibrosis of the left ventricular wall, although the increase in the total fibrotic area was not statistically significant.

Strength training (anaerobic/resistance) increases left ventricular mass thickness without enlargement of the cavity (concentric hypertrophy), which is characterized by increased ratio of wall thickness/diameter of the ventricular cavity. Ventricular wall thickening primarily occurred through an increase in myocyte cross-sectional area. Endurance exercise (aerobic) produces ventricular wall thickening accompanied by ventricular cavity dilatation (eccentric hypertrophy) so that the ratio of wall thickness/ ventricular cavity diameter is relatively constant. ${ }^{8}$

Clinical manifestations of heart remodeling is the change in size, shape and function of the heart that occurs through various channels of molecular, biochemical and mechanical, in response to damage and increase the load of myocardium. ${ }^{9,10}$ The process of cardiac remodeling is influenced by hemodynamic load, neurohumoral activation and other additional factors such as endothelin, cytokines, nitric oxide formation and oxidative stress. ${ }^{11}$ The heart works as a pump of blood to meet the needs of various organs of the body through the adjustment of stroke volume and heart rate. Based on the Frank-Starling mechanism, cardiac muscle cells can increase the strength of contraction when stretched.

During regular endurance exercise or dynamic strength training (strength/power/resistance), there is an increased burden of excessive (overload) volume and/ or pressure on the heart. Increased hemodynamic load raises cardiac adaptation responses including increased muscle mass (hypertrophy) of the heart. Because cardiomyocyte turnover is very slow, increased heart muscle mass occurs through an increase in cell size, both longitudinal and diameter dimensions of the cell. Cardiac output can increase an athlete's endurance of 5-6 $1 / \mathrm{min}$ at rest to $40 \mathrm{l} / \mathrm{min}$ during maximal exercise. As a result, the heart will adjust to the increased volume load by increasing the diameter of the heart cavity. Thus cardiomyocytes will synthesize new contractile proteins and organize new sarcomeres. ${ }^{10,12}$ Enlargement of the heart of this type is known as eccentric hypertrophy.

Regular strength training with high intensity is associated with increased pressure or high peripheral resistance. The heart responds by forming new sarcomeres arranged in parallel and increasing ventricular wall thickness. This situation is referred to as concentric hypertrophy. ${ }^{10,12}$ Although cardiac hypertrophy in athletes can be generally classified into eccentric or concentric hypertrophy, extensive heterogeneity of the size and shape of the athlete's heart was observed.

In general, endurance athletes show cardiac ventricular wall thickening accompanied by significant dilatation of the ventricular cavity. Resistance athlete's heart shows ventricular wall thickening with or without a real ventricular cavity dilatation. It is still debated whether the cardiac enlargement in athletes really is a physiological phenomenon or whether prolonged exercise is a maladaptive phenomenon that can cause heart disease and even sudden death. ${ }^{10}$ Various studies have shown that sudden death in athletes is closely related with the incidence of cardiac arrhythmias. Bradycardia in the resting state that is one hallmark of well-trained athletes may predispose to the onset of atrial or ventricular ectopic beats, atrial fibrillation. ${ }^{13}$ Although various studies on athletes has been widely performed, long-term effects of extensive training and detraining on changes in ventricular myocytes order is still unknown. 
In conclusion, long term aerobic and anaerobic training induces lengthening and thickening of the myocardial cells causing an increase both in the wall thickness and diameter of the left ventricular cavity. During the early stages of aerobic and anaerobic exercise, ventricular wall thickening develops followed by an increase of the left ventricular cavity. Detraining causes a greater regression of the left ventricular cavity compared to the wall thickness. Slight fibrosis develops during long term aerobic and anaerobic exercise, which diminishes during detraining period. Further experiment is needed to study the cause of electrical conduction disturbances in $\mathrm{LVH}$.

\section{Acknowledgments}

We would like thanks the Directorate of Research Community Services of the University of Indonesia for their contribution in this study, Dr. Rostika Flora for her generosity in lending us the animal treadmill, and the Dept of Biochemistry and Molecular Biology for the usage of the laboratory facilities.

\section{REFERENCES}

1. Meijs MFL, de Wind LJ, de Jonge N, Cramer MJM, Bots ML, Mali WPThM, et al. Left ventricular hypertrophy: A Shift in Paradigm. Cur Med Chem. 2007;14:157-71.

2. Froelicher VF, Myers J. Exercise and the heart. $5^{\text {th }}$ ed. Philadelphia: Saunders Elsevier; 2006.
3. Rost R. Athletics and the heart. Chicago: Year Book Medical Publishers;1986.

4. Kannel WB, Levy D, Cupples LA. Left ventricular hypertrophy and risk of cardiac failure: insights from the Framingham Study. J Cardiovasc Pharmacol. 1987;10:S135-40.

5. Lip GYH, Lydakis C, Zarifis J, Messerli FH. Regression of LVH or improved prognosis (or both): what is the question? J Hum Hypertens. 1998;12:423-5.

6. Lorvidhaya P, Karger S, Huang S. Sudden cardiac death in athletes. Cardiol. 2003; 100: 186-95.

7. Bancroft DJ,Gamble M. Theory and practice of histological techniques. $6^{\text {th }}$ ed. Philadeelphia: Churchill Livingstone Elsevier; 2008.

8. Barauna VG, Rosa KT, Irigoyen MC, de Oliveira EM. Effect of resistance training on ventricular function and hypertrophy in a rat model. CM\&R. 2007;2:114 - 20.

9. Mihl C, Dassen WRM, Kuipers H. Cardiac remodeling: concentric versus eccentric hypertrophy in strength and endurance athletes. Neth Heart J. 2008;16:129-33.

10. Weeks KL, McMullen JR. The athlete's heart VS the failing heart: can signaling explain the two distinct outcomes? Physiology. 2011;26:97-105.

11. Cohn JN, Ferrari R, Sharpe N. Cardiac remodelingconcepts and clinical implications: a consensus paper from an international forum on cardiac remodelling. On behalf of an International Forum on Cardiac remodeling. J Am Coll Cardiol. 2000;35:569-82.

12. Wakatsuki T, Schlessinger J, Elson EL. The biochemical response of the heart to hypertension and exercise. Trends Biochem Sci. 2004;29:609-17.

13. Huston TP, Puffer JC, MacMillan RW. The athletic heart syndrome. N Engl J Med. 1985;313:24-32. 